\title{
STUDIES ON BIODEGRADATION OF PHENOLS AND $m$-CRESOLS BY UPFLOW ANAEROBIC SLUDGE BLANKET AND AEROBIC SEQUENTIAL BATCH REACTOR
}

\author{
I.H. FAROOQI* \\ F. BASHEER \\ T. AHMAD
}

Received: $21 / 11 / 07$

Accepted: 14/12/07

\author{
Environmental Engineering Section \\ Department of Civil Engineering \\ Aligarh Muslim University, Aligarh - 202002 (U.P.), India
}

ABSTRACT
Wastewaters from fossil fuel refining, pharmaceuticals, and pesticides are the main sources of
phenolic compounds. Those with more complex structures are often more toxic than the simple
phenol, and yet little is known about the treatment of wastewater containing a mixture of
phenolic pollutants. The present study was aimed at assessing the efficacy of UASB and SBR
for the treatment of mixtures of phenolics compounds.

*to whom all correspondence should be addressed: e-mail: rahziul@yahoo.com

The experiments were conducted in a laboratory scale UASB reactor, which had a volume of $1.414 \mathrm{I}$. A gas-liquid solid separator, GLSS was provided at the top of the reactor. The reactor was operated at constant HRT of $24 \mathrm{~h}$ throughout the study. The reactor was seeded with digested sewage sludge obtained from Okhla Sewage Treatment Plant, New Delhi, India. Initially the microbial culture was acclimatized to phenol concentration of $600 \mathrm{mg}^{-1}$ in UASB. Thereafter, different phenol: m-cresols ratio were introduced, 10:1, 4.5:1, 2.7:1, 1.75:1 and 1.2:1 and the performance of the reactor was evaluated under each case. The second experiment was conducted in a laboratory scale SBR reactor with a working volume of $1.4 \mathrm{I}$. The effluent was drawn from a volumetric exchange ratio of $50 \%$. A fine bubble aerator in the bottom of the column was used to introduce air. The reactor was seeded with aerobic digested sludge obtained from Star Paper Mill, Saharanpur, UP, India. A constant HRT of $12 \mathrm{~h}$ was kept throughout the study. Reactor was operated sequentially with fill, react, settle and draw periods for a cycle of $6 \mathrm{~h}$. In order to establish a viable biomass and minimize any potential toxic effects due to presence of phenolic compounds, the sludge was fed with phenol as batch culture up to $1000 \mathrm{mg} \mathrm{l}^{-1}$ concentration. After acclimatization, different phenol: $\mathrm{m}$ cresol ratio were introduced 6.5:1, 2:1, 1.1:1, 0.5:1 and the performance of the reactor was evaluated under each case. A start up period of 40 days was required to acclimatize the anaerobic bacterial at HRT of $24 \mathrm{hrs}$ for phenol concentration of $200 \mathrm{mg} \mathrm{l}^{-1}$. UASB reactor successfully biodegraded phenol and m-cresol up to a maximum ratio (1.25:1) (300: $\left.250 \mathrm{mg} \mathrm{l}^{-1}\right)$ with $80 \%$ efficiency. A start up period of 30 days was required to acclimatize aerobic bacteria with phenol to concentration up to $1000 \mathrm{mg} \mathrm{l}^{-1}$ as batch culture. The maximum phenol and m-cresol up to (1.1: 1 ) (800: $700 \mathrm{mg} \mathrm{l}^{-1}$ ) was successfully treated with efficiency of $95 \%$ in SBR. The results indicates that anaerobic treatment by UASB and aerobic treatment by SBR can be successfully used for phenol/cresol mixture, representative of major substrates in chemical and petrochemical wastewater and the results shows proper acclimatization period is essential for the degradation of $\mathrm{m}$ - cresol and phenol. Moreover, SBR was found as a better alternative than UASB reactor as it is more efficient and higher concentration of $\mathrm{m}$ cresols can be successfully degraded.

KEYWORDS: Cresol, phenol, aerobic, sequencing batch reactor, granulation 


\section{INTRODUCTION}

Wastewaters from fossil fuel, refining, pharmaceuticals, and pesticides are the main sources of phenolic pollution. Wastewaters from a refinery are a complex mixture of organic and inorganic compounds, often containing more than one type of phenolic compound. Phenol and cresols are major constituents found in refinery effluents (Berne and Cordonnier,1995). A phenol concentration of $1 \mathrm{mg} \mathrm{l}^{-1}$ or greater affects aquatic life. Therefore in most cases stringent effluent discharge limit of less than $0.5 \mathrm{mg} \mathrm{l}^{-1}$ is imposed. Many substituted phenols including chlorophenols, nitrophenols, and cresols have been designated as priority pollutants by U.S. Environmental Protection Agency (EPA) (Keith and Telliard, 1979). Phenols can be removed by solvent extraction, adsorption, chemical oxidation, incineration and other non-biological treatment methods but these methods suffer from serious drawbacks such as high cost and formation of hazardous by products (Loh et al.,2000). Biological degradation is generally preferred due to lower costs and the possibility of complete mineralization However, phenolcontaining wastewater is difficult to treat because of substrate inhibition, whereby microbial growth and concomitant biodegradation of phenol are hindered by the toxicity exerted by high concentrations of the substrate itself. One of the consequences of toxic compounds in biological wastewater treatment is process instability, which can lead to a washout of the effective organisms, sometimes providing little warning of the impending failure (Tay et al., 2004; Yoong et al., 2000). Such toxic wastes are recalcitrant to biodegradation and are toxic to microorganisms.

Tay et al. (2001) investigated the phenol biodegradation with or without glucose as a co substrate in a two litre lab scale up-flow anaerobic sludge blanket reactor (UASB). The reactors were operated at a constant hydraulic retention time of $12 \mathrm{~h}$ with gradual stepwise increase in phenol concentration from 105-1260 $\mathrm{mg} \mathrm{l}^{-1}$. Phenol was successfully degraded with the formation of sludge granules in the reactors with or without glucose supplement. The glucose supplementation accelerated the startup of the reactor and resulted in sludge granulation tends to improving the reactor performance. Fang et al. (1999) conducted experiments in an up-flow anaerobic sludge blanket (UASB) reactor for treating wastewater containing phenol $200 \mathrm{mg} \mathrm{I}^{-1}$ and $\mathrm{m}$-cresol (100 $\mathrm{mg} \mathrm{l}^{-1}$ ) and nitrate at various concentrations and concluded that denitrification occurred without much acclimatization. Denitrifiers outcompeted methanogens for substrates for carbon and electron supplies. Batch test results showed that degradation of $\mathrm{m}$-cresol was enhanced not only by the presence of nitrate but also by the presence of sucrose or phenol as co substrate. Grajales et al. (2003) evaluated the effect of o-cresol, m-cresol on the biodegradation of phenol and $p$-cresol in a continuous system under anaerobic conditions. A continuous experiments were conducted in two $160 \mathrm{ml}$ upward anaerobic sludge bed reactors at organic loading of $3 \mathrm{~kg}$ chemical oxygen demand (COD m $\mathrm{m}^{-3} \mathrm{~d}^{-1}$ ) of phenolic compounds mixture (R1: phenol/p-cresol/o-cresol and R2: phenol/p-cresol/m-cresol). The inoculum used was anaerobic granular sludge adapted to phenol and p-cresol degradation. The results showed that phenol and $p$-cresol biodegradation was not affected by the presence of other isomers. The most important conclusion from this study was that high o-cresol removal efficiency (85\%) was obtained under anaerobic conditions, even when the mixture included $\mathrm{m}$, p-cresol and phenol.

Self-immobilized biofilms in the form of granular aggregates are recent innovation in toxic and high OLRs (Organic Load Rates) wastewater treatment and probably best recognized in upflow anaerobic sludge blanket (UASB) reactor, where anaerobic granules are used for wastewater treatment (Zhou and Fang, 1997; Tay et al., 2001; Kennes et al., 1997). In recent years, research has focused on developing aerobic granules in sequential batch reactor (SBR) (Beun. et al., 1999; Brenner et al., 1992).

Gallego et al. (2003) conducted experiment to study degradation and detoxification of a mixture of persistent compounds (2-chlorophenol, phenol and m-cresol) by using pure and mixed indigenous cultures both in batch and continuous aerobic reactors. Biodegradation was evaluated by determining total phenols, ultraviolet spectrophotometry and chemical oxygen demand (COD). Microbial growth was measured by the plate count method. Scanning electronic microscopy was employed to observe the microbial community in the reactor. Detoxification was evaluated by using Daphnia magna toxicity tests. Individual compounds were degraded by pure bacteria cultures within $27 \mathrm{~h}$. The mixture of 2 chlorophenol $\left(100 \mathrm{mg} \mathrm{l}^{-1}\right)$, 
phenol $\left(50 \mathrm{mg} \mathrm{l}^{-1}\right)$ and $\mathrm{m}$-cresol $\left(50 \mathrm{mg} \mathrm{l}^{-1}\right)$ was degraded by mixed bacteria cultures under batch conditions within $36 \mathrm{~h} ; 99.8 \%$ of total phenols and $92.5 \%$ of COD were removed; under continuous flow conditions $99.8 \%$ of total phenols and $94.9 \%$ of COD were removed. Yu et al. (1996) compared the performance of SBRs with unaerated fill and aerated fill for the treatment of synthetic phenolic wastewater in order to select an appropriate fill mode. At low influent phenol concentrations (e.g. $400 \mathrm{mg} \mathrm{I}^{-1}$ ), the SBR with unaerated fill performed better than the SBR with aerated fill, in which there was a tendency for filamentous bacteria to develop. However, when the influent phenol concentration was high (e.g. $>800 \mathrm{mg} \mathrm{l}^{-1}$ ), phenol accumulated during the fill period in the SBR with unaerated fill became inhibitory to microorganisms.

Aerobic granules have several advantages over conventional activated sludge systems, including a strong, compact microbial structure, good setting ability and high biomass retention (Moy et al., 2002). The present study was aimed at assessing the efficacy of UASB and SBR for treating phenol and $\mathrm{m}$-cresol at different ratio.

\section{MATERIALS AND METHODS}

\subsection{Reactor}

The experiments were conducted in a lab scale UASB reactor, shown in Figure1, which had an internal diameter of $60 \mathrm{~mm}$ and a height of $500 \mathrm{~mm}$. The reactor had a volume of $1.414 \mathrm{I}$. A gas-liquid-solid separator, GLSS, was provided at the top of the reactor. A water seal was attached to maintain liquid level in the reactor. The reactor was operated at constant HRT of 24 $\mathrm{h}$ throughout the study. The temperature was maintained in the range of $30-35^{\circ} \mathrm{C}$ and the $\mathrm{pH}$ of the feed solution was maintained in the range of 7.5-8.0. The reactor was seeded with digested sewage sludge obtained from Okhla Sewage Treatment Plant, New Delhi, India. The seed sludge had a volatile suspended solid (VSS) content of. $31 \mathrm{~g} \mathrm{I}^{-1}$.

The second experiments were conducted in lab scale SBR reactors, shown in Figure 2 Column-type SBRs (5 cm diameter and $100 \mathrm{~cm}$ height) with a working volume of $1.4 \mathrm{~L}$ were used. Effluent was drawn at $50 \mathrm{~cm}$ from the bottom at a volumetric exchange ratio of $50 \%$. The reactor was kept open so that a natural mixed population could develop. A fine bubble aerator in the bottom of the column introduced air. The reactor was seeded with 1-liter aerobic digested sludge, obtained from Star Paper Mill, Saharanpur, India. The sludge had a volatile suspended solid (VSS) content of $3.0 \mathrm{~g} \mathrm{I}^{-1}$.

A constant HRT of $12 \mathrm{~h}$ was kept throughout the study. Reactor was operated sequentially with fill, react, settle and draw periods for a cycle of $6 \mathrm{~h}$. The experiments were performed at room temperature. There were two sampling ports arranged along the height of the column type reactor, one at $50 \mathrm{~cm}$ and other at $30 \mathrm{~cm}$ from the bottom of the reactors. The effluent was collected and withdrawn from the port, which was at $50 \mathrm{~cm}$ height. The $30 \mathrm{~cm}$ height port was used for collection of MLSS and periodical sludge wasting.

\subsection{Feed composition}

Pure crystal phenol was used to prepare stock solution of concentration $20,000 \mathrm{mg} \mathrm{l}^{-1}$. Liquid $m$-cresol was used to prepare stock solution at a concentration of $10,350 \mathrm{mg} \mathrm{I}^{-1}$. During the experiment, the desired concentrations of phenol were obtained by proportionate dilution with water. The feed solution was supplemented with macro and micronutrients to support the growth of microorganisms responsible for degradation of phenols. The nutrients were prepared as:

- Macronutrients: $\mathrm{KH}_{2} \mathrm{PO}_{4}: 20 \mathrm{mg} \mathrm{l}^{-1}, \mathrm{~K}_{2} \mathrm{HPO}_{4}: 30 \mathrm{mg} \mathrm{l}^{-1}, \mathrm{NH}_{4} \mathrm{Cl}: 100 \mathrm{mg} \mathrm{l}^{-1}, \mathrm{CaCl}_{2} \cdot 2 \mathrm{H}_{2} \mathrm{O}: 50$ $\mathrm{mgl}^{-1}, \mathrm{FeSO}_{4} .7 \mathrm{H}_{2} \mathrm{O}: 20 \mathrm{mg} \mathrm{l}^{-1}, \mathrm{MgSO}_{4} .7 \mathrm{H}_{2} \mathrm{O}: 25 \mathrm{mg} \mathrm{l}^{-1}$

- Micronutrients: $\mathrm{H}_{3} \mathrm{BO}_{3}: 0.05 \mathrm{mg} \mathrm{l}^{-1}, \mathrm{ZnCl}_{2}: 0.05 \mathrm{mg} \mathrm{l}^{-1}, \mathrm{CuCl}_{2}: 0.03 \mathrm{mg} \mathrm{l}^{-1}, \mathrm{MnSO}_{4} \cdot \mathrm{H}_{2} \mathrm{O}: 0.05$ $\mathrm{mg} \mathrm{l}^{-1}, \mathrm{COCl}_{2} \cdot 6 \mathrm{H}_{2} \mathrm{O}: 0.05 \mathrm{mg} \mathrm{l}^{-1}, \mathrm{NiCl}_{2}: 0.05 \mathrm{mg} \mathrm{l}^{-1}, \mathrm{AlCl}_{3}: 0.05 \mathrm{mg} \mathrm{l}^{-1}$ (Tay et al., 2001).

Macronutrients and micronutrients stock solutions were prepared at a 1,000 times concentration. For optimal microbial growth $1 \mathrm{ml}$ each was added to the feed solution. Buffer was also added to the feed solution at a concentration of $1000 \mathrm{mg} \mathrm{l}^{-1}$ of $\mathrm{NaHCO}_{3}$. 


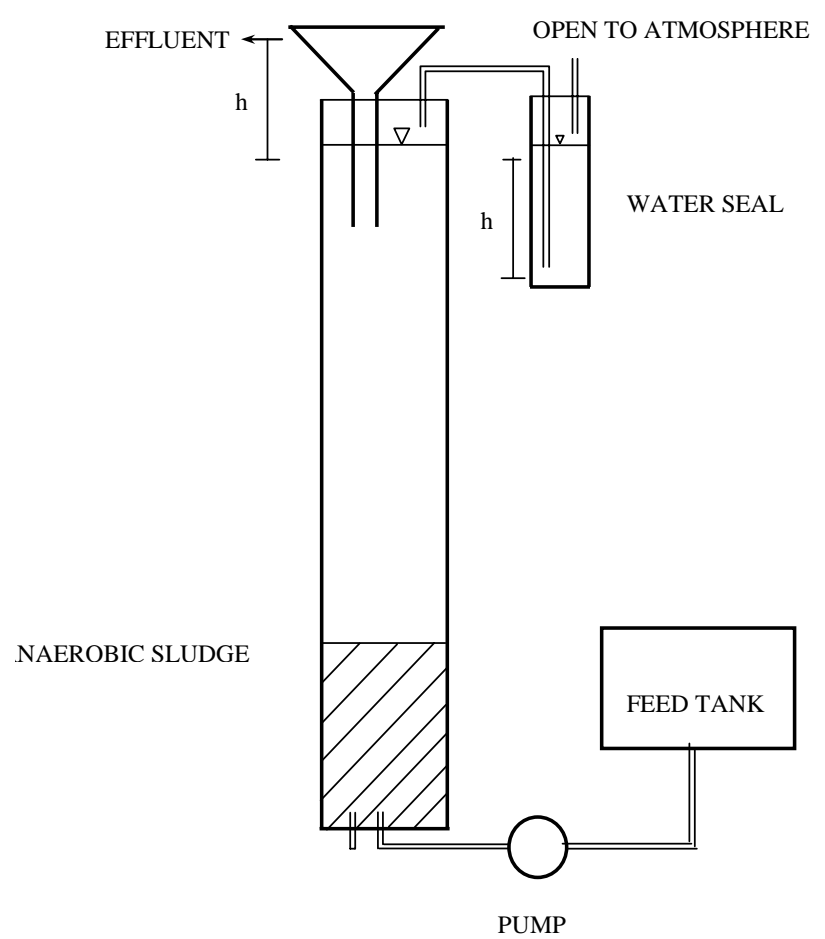

Figure 1. Set up of UASB Reactor

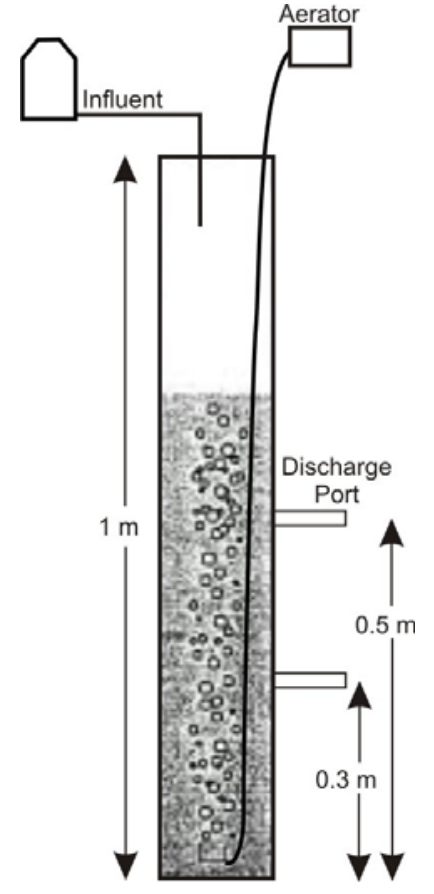

Figure 2. Set up of Aerobic Sequential batch Reactor

\subsection{Analytical methods}

Analysis of phenol was done using SL-196 Elico made UV-VIS Spectrophotometer by direct colorimetric method (4-aminoantipyrine method). The COD, VSS, $\mathrm{pH}$ and alkalinity tests were conducted as per standard methods (APHA, 1995).

\section{RESULTS AND DISCUSSION}

The present study deals with the anaerobic treatment of phenols as mixture of phenol and $\mathrm{m}$ cresol. The study was carried out in a laboratory scale UASB reactor. Initially the reactor was fed with neutralized acetic acid solution for the activation of methanogens. The feed acetate concentration was $1000 \mathrm{mg} \mathrm{l}^{-1}\left(1 \mathrm{~g} \mathrm{COD}^{-1}\right)$ and the hydraulic retention time (HRT) was $24 \mathrm{~h}$. This has resulted in organic loading rate (OLR) of $1 \mathrm{~kg} \mathrm{COD} \mathrm{m}^{-3} \mathrm{~d}^{-1}$. These conditions were continued for 3 weeks till significant COD removal efficiency (80\%) was achieved. Initially the microbial culture was acclimatized to phenol concentration of $600 \mathrm{mg} \mathrm{I}^{-1}$ in UASB for 2 months.

The second study deals with the aerobic treatment of mixture of phenol and cresols. The study was carried out in laboratory scale Sequential Batch Reactor. Initially the sludge was acclimatized with phenol in batch studies. The feed phenol concentration was increased gradually from $200 \mathrm{mg} \mathrm{l}^{-1}$ to $300,400,600,800$ and $1000 \mathrm{mg} \mathrm{l}^{-1}$ after $80-90 \%$ of phenol removal efficiency was reached in each stage. This was continued for 4 weeks. After the acclimatization, the sludge was transferred to the reactor. Thereafter, different phenol: $\mathrm{m}$ cresols ratios were introduced. 6.5:1, 2:1, 1.1:1, 0.5:1 (1300: 200) (1000: 500) (800: 700) (500: $1000 \mathrm{mg} \mathrm{l}^{-1}$. The feed pattern is summarized in Table 1

Table 1. Feed Pattern in the Reactors

\begin{tabular}{lcc}
\hline Feed Pattern & Phenol $\left(\mathrm{mg} \mathrm{l}^{-1}\right)$ & $\mathrm{m}$-Cresol $\left(\mathrm{mg} \mathrm{l}^{-1}\right)$ \\
\hline Preliminary 1 & 1200 & 0 \\
Preliminary 2 & 1500 & 0 \\
Stage 1 & 1300 & 200 \\
Stage 2 & 1000 & 500 \\
Stage 3 & 800 & 700 \\
Stage 4 & 500 & 1000 \\
Stage 5 & - & - \\
\hline
\end{tabular}




\subsection{Biodegradation phenol and $m$-cresol in UASB}

The effect of $\mathrm{m}$-cresol on the phenol degradation by anaerobic bacteria was also assessed in the same UASB reactor that has been acclimatized to $600 \mathrm{mg} \mathrm{l}^{-1}$ of phenol concentration. Different phenols to $m$-cresol ratio were tried and the performance of the reactor was investigated under each case. Initially phenol to $m$-cresol ratio of 10:1 (500: 50 $\mathrm{mg} \mathrm{l}^{-1}$ ) was tried. The total phenols removal efficiency dropped to $57 \%$. However within 6 days the COD removal efficiency recovered and was about $77 \%$. The m-cresol concentration in the feed was gradually increased and different phenol: $m$-cresol ratios applied were 10:1, 4.5:1, 2.7:1, 1.75:1 and 1.2:1 (500:50), (450:100), (400:150), (350:200) and $\left(300: 250 \mathrm{mg} \mathrm{l}^{-1}\right)$ as shown in Figure 3 . The feed was changed after achieving $75 \%$ of COD removal efficiency in each stage.

On day 80 , when phenol to m-cresol ratio was (1.2:1) (300: $250 \mathrm{mg} \mathrm{l}^{-1}$ ), the total phenols removal efficiency decreased to $42 \%$ as shown in Figure 4 . However, by day 100 the reactor again achieved $78 \%$ COD removal efficiency for the same phenol to $\mathrm{m}$ cresol ratio. It can be concluded from the study that higher concentration of $m$-cresols could be degraded successfully provided sufficient acclimatization is provided.

It has been reported in literature that around 6 weeks to 10 months time is required for acclimation of microorganisms to phenols. The acclimatization period depends upon the nature of inocula and the extent of acclimatization required. In our experiment the acclimatization period was 45 days.

From results obtained for $m$-cresol study, it is clear that the ratio of phenol/m-cresol determined their degradation in the reactor. Higher ratios of phenol/ $\mathrm{m}$-cresols could be degraded successfully by gradually increasing the ratio and providing sufficient time to microorganisms to adjust to new feed composition. Though many scientist have reported the inhibitive nature of intermediate product of phenol degradation i.e. 4-hydroxy benzoate, to $m$-cresol degradation (Ramanand and Suflita, 1991). Tay (2001) could eliminate only $20 \%$ of m-cresol from a mixture with phenol at ratio (3:1) (900:320 $\left.\mathrm{mg} \mathrm{l}^{-1}\right)$. In general, this result suggests the variable capacity of the microorganisms to degrade isomers and the difference in pathways that can be followed in the degradation under anaerobic conditions. Further, it is also found that phenol as a single substrate and phenol / $\mathrm{m}$-cresol mixture can be treated effectively without any carbohydrate co-substrate. Co-Substrate addition to phenol degradation has been a common practice (Tay et al., 2001; Kennes et al., 1997).

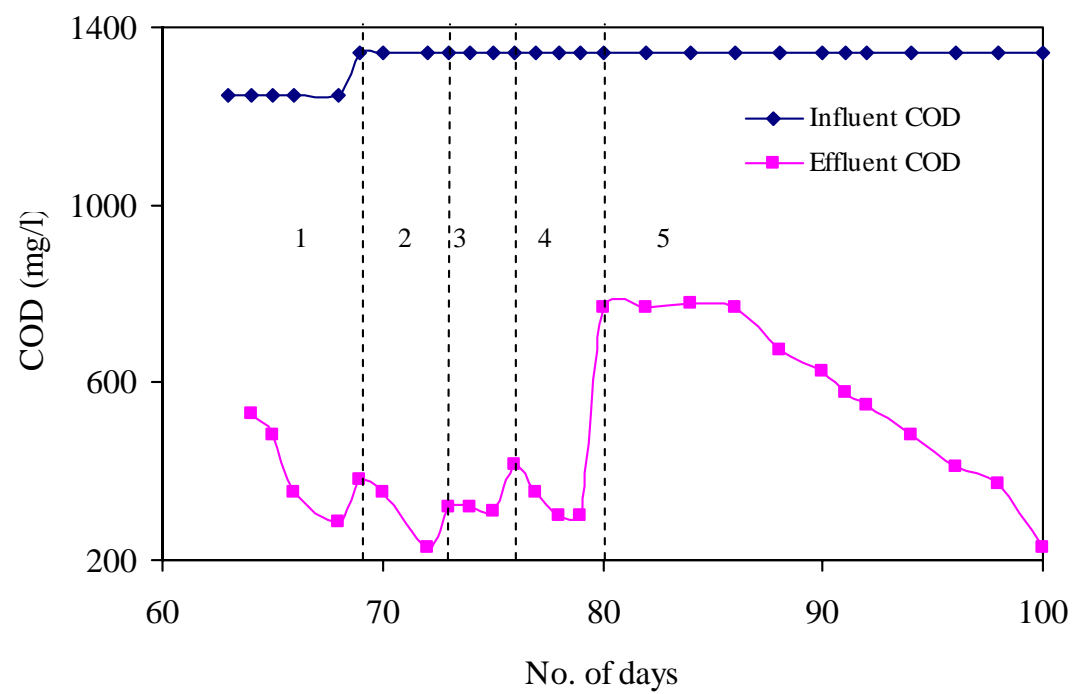

Figure 3. Performance of reactor with mixture of phenol and m-cresol in UASB 


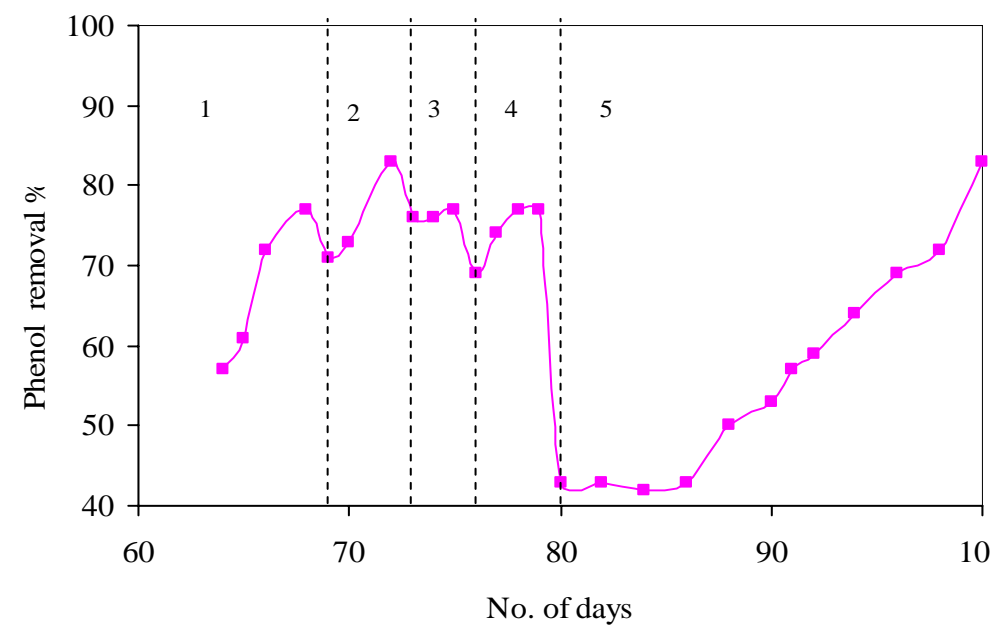

Figure 4. Variation of total phenols removal efficiency with time

\subsection{Biodegradation of mixture of phenol and $\mathrm{m}$-cresol in SBR}

The biodegradability studies for the mixture of phenols and $\mathrm{m}$-cresol were also evaluated under aerobic sequential batch reactor. The reactor was fed with phenol for first four days of operation so as to reactivate phenol-degrading bacteria. Subsequently synthetic mixture of phenol and $\mathrm{m}$-cresol solution was fed to reactor. The initial concentration of $\mathrm{m}$-cresol was kept at $200 \mathrm{mg} \mathrm{l}^{-1}$ and the phenol concentration was reduced to $1300 \mathrm{mg} \mathrm{l}^{-1}$ from $1500 \mathrm{mg} \mathrm{l}^{-1}$ in the acclimation period. The presence of $\mathrm{m}$-cresol resulted in reduced substrate percent removal, which indicated the inhibitory effect of $\mathrm{m}$-cresol. The reactor regained its substrate removal efficiency within four days and it reaches up to $90-95 \%$.

The proportion of m-cresol in the feed solution was increased gradually from $200 \mathrm{mg} \mathrm{I}^{-1}$ to 500 , $700,1000 \mathrm{mg} \mathrm{l}^{-1}$ and correspondingly the phenol concentration was reduced from $1300 \mathrm{mg} \mathrm{l}^{-1}$ to $1000,800,500 \mathrm{mg} \mathrm{l}^{-1}$ I respectively. The response of the reactor to the increase in $\mathrm{m}$-cresol concentration was monitored closely during every stage of transitional period and plotted in the form of graphs depicted from Figures 5, 6 and 7.

From day 8 the reactor was considered to be operating at a steady state condition because relatively stable effluent quality was achieved. The treatment efficiency reduced drastically in phase 6 . The influent concentrations of phenol and m-cresol in this phase were $500 \mathrm{mg} \mathrm{l}^{-1}$ and $1000 \mathrm{mg} \mathrm{l}^{-1}$ respectively. The biomass concentration in reactor starts decreasing gradually. Reactor was unable to remove the substrates biologically and the substrates concentration in the effluent increased sharply. Thus it was concluded that the system failure took place in reactor and it was stopped.

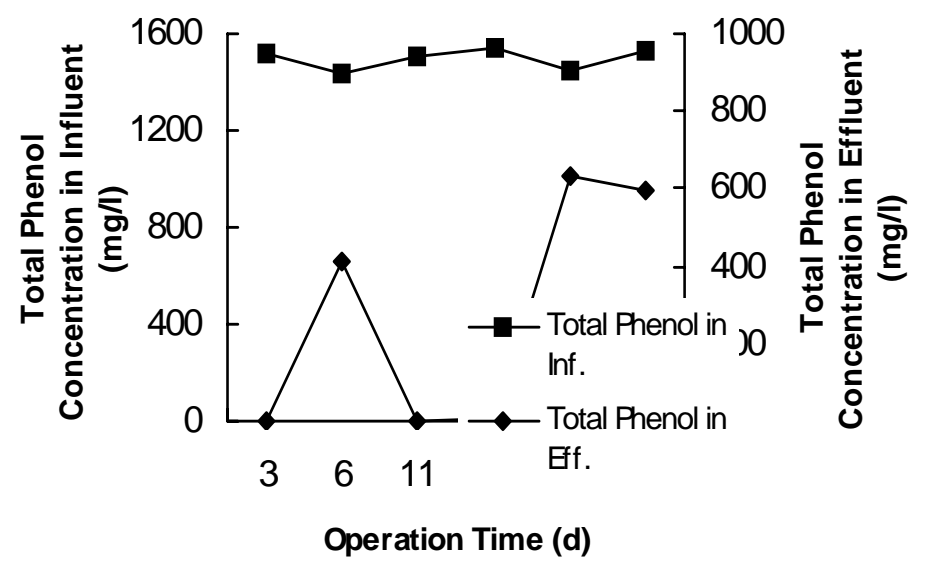

Figure 5. Total Phenol in SBR 


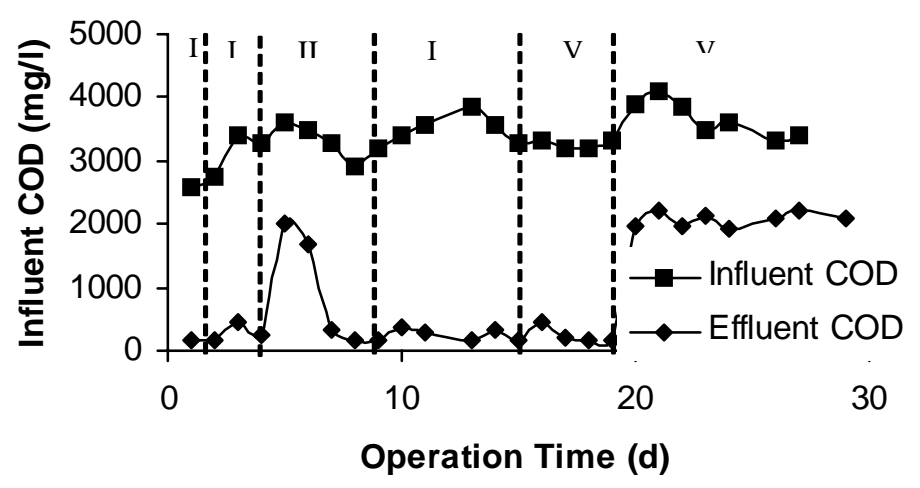

Figure 6. Performance of Reactor with mixture of Phenol and m-Cresol in SBR

\section{CONCLUSIONS}

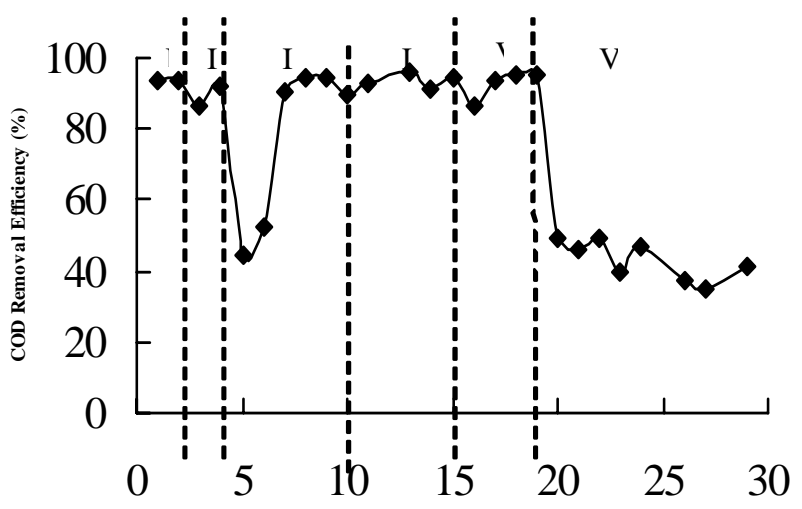

Operation Time (d)

Figure 7. COD removal Efficiency in SBR

The anaerobic treatment represents a good alternative for the removal of aromatic compounds from industrial wastewaters of complex mixture. A start up period of 40 days was required to acclimatize the anaerobic bacteria with $200 \mathrm{mg} \mathrm{l}^{-1}$ of phenol at HRT of $24 \mathrm{hrs}$. The maximum phenol concentration of $600 \mathrm{mg} \mathrm{I}^{-1}$ was successfully treated with efficiency of $80 \%$. Introduction of $\mathrm{m}$-cresols in the phenols inhibited treatment efficiency temporarily. However, after acclimatization, $m$-cresol was also degraded effectively. UASB reactor was successfully used to study the biodegradation of phenol and $m$-cresol up to ratio (1.25:1) $\left(300: 250 \mathrm{mg} \mathrm{l}^{-1}\right)$ and the results shows that it is important to consider phenol/cresol ratio to avoid toxic effects.

While for aerobic studies a start up period of 30 days was required to acclimatize the bacteria with phenol, the concentration of phenol was gradually increased from $200 \mathrm{mg} \mathrm{I}^{-}$to $1000 \mathrm{mg} \mathrm{I}^{-1}$, as batch culture. The aerobic culture was then transferred to the SBR wherein m-cresol was also introduced with the phenols. Introduction of $\mathrm{m}$-cresol in the phenol inhibited treatment efficiency temporarily. The maximum phenol and m-cresol up to (1.1: 1) (800: $700 \mathrm{mg} \mathrm{l}^{-1}$ ) was successfully treated with efficiency of $95 \%$ in SBR.

The results indicate that aerobic treatment using SBR and anaerobic treatment using UASB can be successfully used for biodegradation of phenolic wastewater of phenol / cresol mixture, representative of major substrates in chemical and petrochemical wastewater and the results shows that it is important to consider phenol/cresol ratio to avoid toxic effects. Moreover, SBR was found as a better alternative than UASB reactor as it is more efficient and higher concentration of $\mathrm{m}$ cresols can be successfully degraded 


\section{REFERENCES}

1. American Public Health Association (APHA) (1995) Standard Methods for the examination of water and wastewater, $19^{\text {th }}$ Ed. Washington D.C.

2. Berne F. and Cordonnier J. (1995) Treatment of spent caustic, Industrial waste treatment: refining petrochemicals and gas processing techniques, Gulf Publishing Company, Paris, 124-153.

3. Beun J.J., Hendriks A., Van Loosdrecht M.C.M., Morgenroth E., Wilderer P.A. and Heijnen J.J. (1999) Aerobic granulation in a sequencing batch reractor, Water Research, 33, 22832290.

4. Brenner A., Chozick R. and Irvine R.L. (1992) Treatment of high strength, mixed phenolic waste in an SBR, Water Environ. Res., 64, 128-133.

5. Fang H. and Zhou G. (1999) Interactions of methanogens and denitrifiers in degradation of phenols, J. Environ. Engrg. ASCE, 125, 57-63.

6. Gallegoa A., Fortunatoa M.S., Fogliab J., Rossia S., Geminia V., Gomezb L., Gomezb C.E., Higab L.E. and Korola S.E. (2003) Biodegradation and detoxi!cation of phenolic compounds by pure and mixed indigenous cultures in aerobic reactors, International Biodeterioration \& Biodegradation, 52, $261-267$.

7. Keith L.H. and Telliard W.A. (1979) Priority pollutants I - a perspective view, Environ. Sci. Technol.,13, 416-423.

8. Kennes C., Mendez R. and Lema J.M. (1997) Metahanogenic degradation of p-cresol in batch and in continuous UASB reactors, Water Res, 31(7), 1549-1554.

9. Loh K.C., Chung T.S. and Ang W.F. (2000) Immobilized cell membrane bioreactor for high strength phenol wastewater, J. Environ. Engrg. ASCE, 126(1), 75-79.

10. Moy B.Y.P., Tay J.H., Toh S.K., Liu Y. and Tay S.T.L. (2002) High organic loading influences the physical characteristics of aerobic granules, Letter in Applied Microb., 34, 407-412.

11. Puig-Grajales L., Rodriguez-Nava O. and Razo-Flores E. (2003) Simultaneous biodegradation of phenol and 3,4-dimethyl phenol mixture under dentrifying conditions, Water Sci. Technol., 48(6), 171-178.

12. Ramanand K. and Suflita J.M. (1991) Anaerobic biodegradation of m-cresol, Applied Environ. Microbiol., 57, 1689-1695.

13. Tay J.H., He Y.X. and Yan Y.G. (2001) Improved anaerobic degradation of phenol with supplemental glucose, J.Environ. Engrg. ASCE, 127(11), 38-45.

14. Tay J.H., He Y.X. and Yan Y.G. (2001) Improved anaerobic degradationof phenol with supplemented glucose, J. Environ. Engrg. ASCE., 127(1), 38-45.

15. Tay J.H., Jiang H. and Tay S.T. (2004) High rate biodegradation of phenol by aerobically grown microbial granules, J. Environ. Engrg. ASCE., 130(12), 1415-1428.

16. Yoong E.T., Lant P.A. and Green P.F. (2000) In situ respirometry in an SBR treating wastewater with high phenol concentrations, Water Res., 34(1), 239-245.

17. Yu H.Q. and Gu G.W. (1996) Treatment of phenolic wastewater by sequencing batch ractor with aereated and unaerated fills, Waste management, 16(7), 561-66.

18. Zhou G.M., Fang H.H.P. (1997) Co-degradation of phenol and m-cresol in a UASB reactor, Bioresource Technol., 61, 47-52. 